\title{
SYNTHESIS OF NOVEL SCHIFF BASE DERIVATIVES OF TACRINE AND INVESTIGATION OF THEIR ACETYLCHOLINESTERASE INHIBITION POTENCY
}

\author{
Elif (Aynaci) Koyuncu ${ }^{1,2, *}$, Ahmet Yaşar $^{3}$, Fatma Arslan ${ }^{3}$, Nurşen Sari ${ }^{3}$ \\ ${ }^{1}$ Department of Chemistry, Institute of Sciences, Gazi University, 06500 Ankara, Turkey \\ ${ }^{2}$ Department of Chemistry, Faculty of Engineering and Natural Sciences, \\ Istanbul Medeniyet University, 34700 Istanbul, Turkey \\ ${ }^{3}$ Department of Chemistry, Faculty of Science, Gazi University, 06500 Ankara, Turkey
}

elif.koyuncu@medeniyet.edu.tr

\begin{abstract}
Investigation of acetylcholinesterase (AChE) inhibition potency of some new Schiff base derivatives of tacrine (9-amino-1,2,3,4-tetrahydroacridine) was reported in this paper. Novel Schiff base derivatives of tacrine (3a-g) have been synthesized, and they have been characterized by several methods (FTIR, ${ }^{1} \mathrm{H}-\mathrm{NMR},{ }^{13} \mathrm{C}-\mathrm{NMR}$, etc.). Then, inhibition effects on AChE by the synthesized compounds have been investigated by the spectrophotometric Ellman method. $\mathrm{IC}_{50}, K_{\mathrm{i}}, K_{\mathrm{M}}$ and $V_{\max }$ values and inhibition types have been determined. It was seen that all compounds had the property of a water-soluble reversible AChE inhibitor. Structure 3a was found to be the most potent inhibitor, with the $\mathrm{IC}_{50}$ value of $22.1 \pm$ $1.11 \mathrm{nM}$ (tacrine's $\mathrm{IC}_{50}$ value was calculated as $34.1 \mathrm{nM}$ ).
\end{abstract}

Key words: inhibition; acetylcholinesterase; tacrine; Schiff base; inhibition type

\section{СИНТЕЗА НА НОВИ ДЕРИВАТИ НА ШИФОВИ БАЗИ НА ТАКРИН И ИСПИТУВАњЕ НА НИВНАТА СПОСОБНОСТ ЗА ИНХИБИЦИЈА НА АЦЕТИЛХОЛИНЕСТЕРАЗА}

Во овој труд е опишано испитувањето на способноста за инхибиција на холинестеразата (AChE) на некои деривати на Шифови бази на такрин (9-амино-1,2,3,4-тетрахидроакридин). Синтетизирани се нови деривати на такрин (3a-g) кои се карактеризирани со неколку методи (FT$\mathrm{IR},{ }^{1} \mathrm{H}-\mathrm{NMR},{ }^{13} \mathrm{C}-\mathrm{NMR}$, etc.). Испитани се инхибициските ефекти на синтетизираните соединенија врз $\mathrm{AChE}$ со спектроскопскиот метод на Ellman. Определени се вредностите на $\mathrm{IC}_{50}, K_{\mathrm{i}}, K_{\mathrm{M}}$ и $V_{\max }$, како и типот на инхибиција. Утврдено е дека сите соединенија имаат својство на во вода растворлив реверзибилен инхибитор на $\mathrm{AChE}$. Најдено е дека 3a е најмоќен инхибитор со вредност на IC 50 $_{0}$ од $22.1 \pm 1.11 \mathrm{nM}$ (пресметано е дека вредноста $\mathrm{IC}_{50}$ на такрин изнесува $34.1 \mathrm{nM}$ ).

Клучни зборови: инхибиција; ацетилхолинестераза; Шифови бази; тип на инхибиција

\section{INTRODUCTION}

Alzheimer's disease (AD) is a chronic neurodegenerative disease which is characterized by memory loss, difficulty in speaking, problems with communication and reasoning [1-3]. There are many potential causes for the emergence of this disease, such as genetic factors, autoimmune reactions, and protein plaques and tangles $[4$,
5]. One promising explanation is the cholinergic hypothesis, that $\mathrm{AD}$ is caused by reduced synthesis of the neurotransmitter acetylcholine (ACh) [1]. ACh $\left(\mathrm{CH}_{3} \mathrm{COOCH}_{2} \mathrm{CH}_{2} \mathrm{~N}^{+}\left(\mathrm{CH}_{3}\right)_{3}\right)$ is an alkaloid which was the first discovered neurotransmitter. It is an ester of choline and acetic acid [6, 7]. It has a great biological importance. This ester is responsible for carrying nerve impulses. It is associated with dementia, AD, and Parkinson's disease [7]. 
The primary function of acetylcholinesterase (AChE) is terminating cholinergic neurotransmission by rapid splitting of Ach [6]. Increasing the level of ACh with AChE inhibitors is an efficient strategy for $\mathrm{AD}$ therapies [8,9]. Many inhibitors such as tacrine, donepezil, and physostigmine are used as drugs for $\mathrm{AD}$ treatment (Fig. 1) [10]. $\mathrm{AChE}$ inhibitors have the potential to alleviate neurodegenerative diseases and dementia [11].<smiles>Nc1c2c(nc3ccccc13)CCCC2</smiles>

(a)

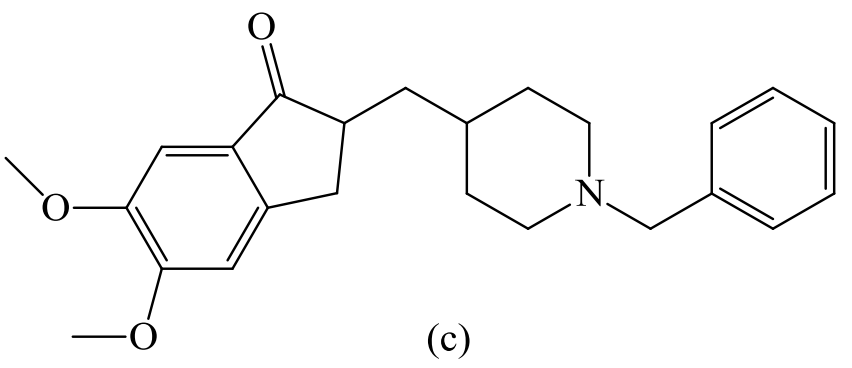<smiles>Nc1c2c([nH+]c3ccccc13)CCCC2</smiles>

(b)

Fig. 1. (a) Tacrine. (b) Tacrine with protonated acridine nitrogen [12]. (c) Donepezil. (d) Physostigmine.

AChE (E.C. 3.1.1.7) is a hydrolase that hydrolyzes neurotransmitter ACh. AChE's active site comprises 2 subsites, the esteratic site and the anionic site [6]. The catalytic triad within the esteratic site, with amino acid positions, for electric eel AChE is follows: Ser 200, His 440 and Glu 327 [13-15]. The anionic site is composed of the aromatic amino acids Trp 86, Tyr 337 and Phe 338 for murine AChE $[13,16]$ or Trp 84, Tyr 121 and Phe 330 for electric eel AChE $[13,17,18]$.

Tacrine (9-amino-1,2,3,4-tetrahydroacridine) is a reversible $\mathrm{AChE}$ inhibitor, and it was the first cholinesterase inhibitor approved by US FDA (Food and Drug Administration) for the treatment of AD [19-21]. It is known, as a result of investigation of X-ray crystal structure of tacrine-AChE complex that a hydrogen bond occurs between the backbone carbonyl oxygen of His 440 in the catalytic triad and the hydrogen of the protonated acridine nitrogen of tacrine (Fig. 1) [12, 22]. It is also known that there is $\pi-\pi$ stacking of two aromatic rings of tacrine between indol ring of $\operatorname{Trp} 84$ and phenyl ring of Phe 330 [12, 22].

The synthesis of different AChE inhibitor derivatives or hybrid molecules has attracted attention in recent years (for example, piperidine de- rivatives [23], tetrazole derivatives [3], hydroxyquinoline derivatives [24], isoquinolines [25], carbamate derivatives [26], $\beta$-lactam analogs and Schiff bases [from 2-naphtaldehyde and substituted aniline derivatives] [27], and coumarin derivatives [28]). Because tacrine is a well-known cholinesterase inhibitor for the treatment of $\mathrm{AD}$, researchers have focused on the development of more active and selective ligands than unmodified tacrine. As of 2019, many tacrine derivatives have been synthesized, their AChE inhibition effects have been investigated, and most have been found more active than tacrine. For example, tacrinemelatonin hybrids $[29,30]$, tacrine-ferulic acid hybrids [31, 32], tacrine-lipoic acid [33] and tacrinecurcumin hybrids [34] have been investigated.

In this study, we report synthesis, characterization and AChE inhibition properties of new Schiff base derivatives of tacrine. Schiff base derivatives of tacrine (3a-g) were synthesized with different aldehydes (salicylaldehyde and its derivatives, 2a-g) (Fig. 2). Then, inhibition effects on $\mathrm{AChE}$ of the synthesized compounds were investigated, and $\mathrm{IC}_{50}$ and $K_{\mathrm{i}}$ values were determined. Inhibition types of these inhibitors have been determined also. 


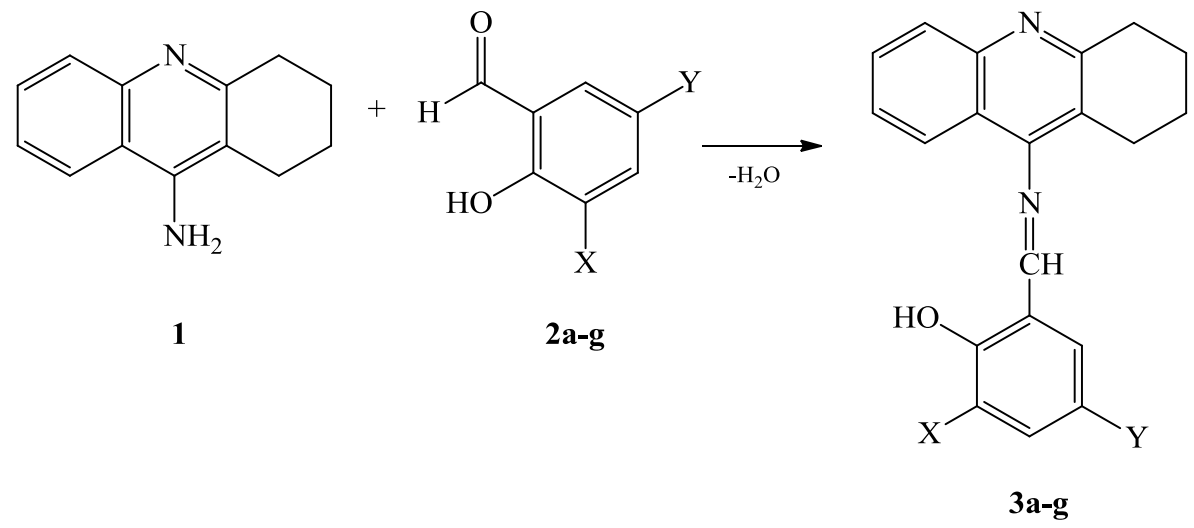

Fig. 2. General reaction scheme.

1 tacrine, 2a 5-fluoro-3-methylsalicylaldehyde, 2b 2-hydroxy-5-methylbenzaldehyde, 2c 3-chloro-5-fluorosalicylaldehyde, 2d 5-bromosalicylaldehyde, 2e 5-chlorosalicylaldehyde, 2f 5-fluorosalicylaldehyde, $2 \mathrm{~g}$ salicylaldehyde. 3a X: - $\mathrm{CH}_{3}$, Y: -F; 3b X: -H, Y: - $\mathrm{CH}_{3}$; 3c X: -Cl, Y: -F; 3d X: -H, Y: -Br; 3e X: -H, Y: -Cl; 3f X: -H, Y: -F; 3g X: -H, Y: -H.

\section{EXPERIMENTAL}

\subsection{Materials and methods}

All organic solvents used in this study were purified according to standard methods. The aldehydes (salicylaldehyde, 5-bromosalicylaldehyde, 5chlorosalicylaldehyde, 5-fluorosalicylaldehyde, 5fluoro-3-methylsalicylaldehyde, 3-chloro-5-fluorosalicylaldehyde, 2-hydroxy-5-methylbenzaldehyde), tacrine hydrochloride (9-amino-1,2,3,4-tetrahydroacridine hydrochloride hydrate), acetylcholinesterase (E.C. 3.1.1.7, purified from Electrophorus electricus [electric eel] Type V-S, activity of $100 \mathrm{unit} / \mathrm{ml}$ ) acetylthiocholine iodide (ATCh), and 5,5'-dithiobis-(2-nitrobenzoic acid) (DTNB, Ellman's reagent) were purchased from SigmaAldrich. Elemental analysis for $\mathrm{C}, \mathrm{H}$, and $\mathrm{N}$ was carried out on a LECO 932 elemental analyzer. ${ }^{1} \mathrm{H}$ $\mathrm{NMR}$ and ${ }^{13} \mathrm{C}-\mathrm{NMR}$ spectra were recorded employing a Bruker Ultrashield AC300 Plus 300 $\mathrm{MHz}$ spectrometer, with DMSO- $\mathrm{d}_{6}$ as solvent. Chemical shifts $(\delta)$ are given in ppm relative to TMS. IR spectra were recorded on a Perkin Elmer Spectrum Two FT-IR spectrometer. Thermogravimetric analysis (TGA) was performed on a Seiko 6300 Model Thermal Analyzer in the temperature range of $0-900{ }^{\circ} \mathrm{C}$ under nitrogen atmosphere. Melting points were determined with a Gallenkamp melting point apparatus.

\subsection{Synthesis of Schiff base derivatives of tacrine (general method)}

Schiff base derivatives were synthesized by following a general method (except 3e). Schiff base derivatives (except 3e) were prepared by reacting of tacrine $\left(1.0 \cdot 10^{-3} \mathrm{~mol}\right)$ in hot methanol $(10.0 \mathrm{ml})$ with $2 \mathbf{a}-\mathrm{g}\left(1.0 \cdot 10^{-3} \mathrm{~mol}\right.$, except $\left.2 \mathbf{e}\right)$ in methanol $(10.0 \mathrm{ml})$ and stirring for $4 \mathrm{~h}$ under a reflux condenser at $70{ }^{\circ} \mathrm{C}$. Thus tacrine-Schiff bases were obtained (Fig. 2). After the mixtures cooled to room temperature, tacrine-Schiff base solutions were concentrated through evaporation, to half their original volumes. After storing the solutions for 2 days, the solid complexes formed were collected by filtration and then dried in a desiccator over $\mathrm{CaCl}_{2}$. Compound $3 \mathbf{e}$ was prepared by reacting of tacrine $\left(1.0 \cdot 10^{-3} \mathrm{~mol}\right)$ in hot DMSO $(2.5 \mathrm{ml})$ with $2 \mathrm{e}(5-$ chlorosalicylaldehyde, $1.0 \cdot 10^{-3} \mathrm{~mol}$ ) in DMSO $(10.0 \mathrm{ml})$ and stirring for $4 \mathrm{~h}$ under a reflux condenser at $70{ }^{\circ} \mathrm{C}$. After the mixture cooled to room temperature, $3 \mathbf{e}$ was collected by filtration, washed with cold ethanol, and recrystallized from ethanol.

\subsection{AChE activity assay}

AChE activity measurements were performed at $30^{\circ} \mathrm{C}$, according to the spectrophotometric assay of Ellman [35]. ATCh was used as substrate for all experiments. The reaction took place in a final volume of $3.0 \mathrm{ml}$ of phosphate-buffered solution, $\mathrm{pH}$ 8.0, containing $\mathrm{AChE}(25.0 \mu \mathrm{l}, 5.0$ unit $/ \mathrm{ml})$, DTNB (50.0 $\mu \mathrm{l}, 0.01 \mathrm{M})$, ATCh $(39.5 \mu \mathrm{l}$, $7.6 \cdot 10^{-3} \mathrm{M}$ ), and inhibitor solution (varying from $5.0 \cdot 10^{-6}$ to $2.5 \cdot 10^{-10} \mathrm{M}$ ), to produce the yellow anion of 5-thio-2-nitrobenzoic acid (Fig. 3). After 30 minutes' incubation, the absorbance of the mixture was measured with the spectrophotometer, at 412 $\mathrm{nm}$. One sample without inhibitor was always present to yield the $100 \%$ of AChE activity. The $\mathrm{IC}_{50}$ and $K_{\mathrm{i}}$ values were calculated with GraphPad Prism 6 (GraphPad Software). Inhibition types were determined in the absence and presence of inhibitor $\left(1.0 \cdot 10^{-7}, 5.0 \cdot 10^{-8}\right.$ and $\left.1.0 \cdot 10^{-8} \mathrm{M}\right)$ from Lineweaver-Burk plots. Each determination was repeated three times and the average values were reported. 


\section{RESULTS AND DISCUSSION}

\subsection{Chemistry}

The route for the synthesis of Schiff base derivatives (3a-g) is illustrated in Figure 2. The reac- tion of tacrine (1) and different aldehydes (2a-g) in refluxing methanol (DMSO for $\mathbf{3 e}$ ) at $70{ }^{\circ} \mathrm{C}$ gave new Schiff base derivatives (3a-g).

Analytical data and some of the physical properties of the Schiff base derivatives of tacrine are summarized in Table 1.

Table 1

Analytical data of Schiff base derivatives of tacrine

\begin{tabular}{|c|c|c|c|c|c|c|c|}
\hline & \multirow[t]{2}{*}{ Compounds } & \multirow{2}{*}{$\begin{array}{c}\text { Empiric formula } \\
\text { (Formula weight, g/mol; } \\
\text { obtained amount, g; } \\
\text { yield } \% \text { ) }\end{array}$} & \multicolumn{4}{|c|}{$\begin{array}{l}\text { Analysis \% } \\
\text { Found (calcd) }\end{array}$} & \multirow{2}{*}{$\begin{array}{l}\text { M.p. }\left({ }^{\circ} \mathrm{C}\right) \\
\text { Colour }\end{array}$} \\
\hline & & & $\mathrm{C}$ & $\mathrm{H}$ & $\mathrm{N}$ & $S$ & \\
\hline $3 \mathbf{a}$ & $\begin{array}{c}\text { (Z)-4-fluoro-2-methyl-6-(((1,2,3,4- } \\
\text { tetrahydroacridin-9- } \\
\text { yl)imino)methyl)phenol }\end{array}$ & $\begin{array}{c}\mathrm{C}_{21} \mathrm{H}_{19} \mathrm{~N}_{2} \mathrm{FO} \cdot 2 \mathrm{H}_{2} \mathrm{O} \\
(370 ; 0.158 ; 43)\end{array}$ & $\begin{array}{l}68.15 \\
(68.04)\end{array}$ & $\begin{array}{c}6.52 \\
(6.21)\end{array}$ & $\begin{array}{l}7.13 \\
(7.56)\end{array}$ & - & $\begin{array}{c}215-218 \\
\text { Straw yellow }\end{array}$ \\
\hline $3 b$ & $\begin{array}{l}\text { (Z)-4-methyl-2-(((1,2,3,4- } \\
\text { tetrahydroacridin-9- } \\
\text { yl)imino)methyl)phenol }\end{array}$ & $\begin{array}{c}\mathrm{C}_{21} \mathrm{H}_{20} \mathrm{~N}_{2} \mathrm{O} \cdot 2 \mathrm{H}_{2} \mathrm{O} \\
(352 ; 0.135 ; 39)\end{array}$ & $\begin{array}{c}71.84 \\
(71.59)\end{array}$ & $\begin{array}{c}6.79 \\
(6.82)\end{array}$ & $\begin{array}{l}7.63 \\
(7.95)\end{array}$ & - & $\begin{array}{l}\text { 160-162 } \\
\text { Fawn }\end{array}$ \\
\hline $3 c$ & $\begin{array}{c}\text { (Z)-2-chloro-4-fluoro-6-(((1,2,3,4- } \\
\text { tetrahydroacridin-9- } \\
\text { yl)imino)methyl)phenol }\end{array}$ & $\begin{array}{c}\mathrm{C}_{20} \mathrm{H}_{16} \mathrm{~N}_{2} \mathrm{ClFO} \cdot 2 \mathrm{H}_{2} \mathrm{O} \\
(390.5 ; 0.20 ; 52)\end{array}$ & $\begin{array}{c}62.09 \\
(61.56)\end{array}$ & $\begin{array}{c}4.82 \\
(5.12)\end{array}$ & $\begin{array}{l}6.74 \\
(7.17)\end{array}$ & - & $\begin{array}{l}\text { 201-203 } \\
\text { Yellow }\end{array}$ \\
\hline 3d & $\begin{array}{l}\text { (Z)-4-bromo-2-(((1,2,3,4- } \\
\text { tetrahydroacridin-9- } \\
\text { yl)imino)methyl)phenol }\end{array}$ & $\begin{array}{c}\mathrm{C}_{20} \mathrm{H}_{17} \mathrm{~N}_{2} \mathrm{BrO} \cdot \mathrm{H}_{2} \mathrm{O} \\
(399 ; 0.181 ; 47)\end{array}$ & $\begin{array}{l}59.75 \\
(60.15)\end{array}$ & $\begin{array}{c}4.38 \\
(4.76)\end{array}$ & $\begin{array}{l}6.93 \\
(7.02)\end{array}$ & - & $\begin{array}{c}\text { 209-211 } \\
\text { Straw yellow }\end{array}$ \\
\hline $3 e$ & $\begin{array}{l}\text { (Z)-4-chloro-2-(((1,2,3,4- } \\
\text { tetrahydroacridin-9- } \\
\text { yl)imino)methyl)phenol }\end{array}$ & $\begin{array}{c}\mathrm{C}_{20} \mathrm{H}_{17} \mathrm{~N}_{2} \mathrm{ClO} .0 .5 \\
\mathrm{DMSO} \cdot 4 \mathrm{H}_{2} \mathrm{O} \\
(447.5 ; 0.242 ; 55)\end{array}$ & $\begin{array}{l}52.16 \\
(51.74)\end{array}$ & $\begin{array}{c}5.59 \\
(5.04)\end{array}$ & $\begin{array}{l}6.62 \\
(7.10)\end{array}$ & $\begin{array}{c}3.58 \\
(3.57)\end{array}$ & $\begin{array}{l}225-227 \\
\text { Brown }\end{array}$ \\
\hline 3f & $\begin{array}{l}\text { (Z)-4-fluoro-2-(((1,2,3,4- } \\
\text { tetrahydroacridin-9- } \\
\text { yl)imino)methyl)phenol }\end{array}$ & $\begin{array}{c}\mathrm{C}_{20} \mathrm{H}_{17} \mathrm{~N}_{2} \mathrm{FO} \cdot 1 \cdot 5 \mathrm{H}_{2} \mathrm{O} \\
(347 ; 0.133 ; 39)\end{array}$ & $\begin{array}{l}68.55 \\
(69.00)\end{array}$ & $\begin{array}{c}5.98 \\
(5.76)\end{array}$ & $\begin{array}{l}8.53 \\
(8.07)\end{array}$ & - & $\begin{array}{l}\text { 219-220 } \\
\text { White }\end{array}$ \\
\hline $3 g$ & $\begin{array}{l}\text { (Z)-2-(((1,2,3,4-tetrahydroacridin- } \\
\text { 9-yl)imino)methyl)phenol }\end{array}$ & $\begin{array}{l}\mathrm{C}_{20} \mathrm{H}_{18} \mathrm{~N}_{2} \mathrm{O} \cdot 4 \mathrm{H}_{2} \mathrm{O} \\
(374 ; 0.15 ; 41)\end{array}$ & $\begin{array}{l}64.17 \\
(64.25)\end{array}$ & $\begin{array}{c}4.81 \\
(5.25)\end{array}$ & $\begin{array}{c}4.42 \\
(4.01)\end{array}$ & - & $\begin{array}{l}165-168 \\
\text { Brown }\end{array}$ \\
\hline
\end{tabular}

Thermal data of derivatized tacrine molecules are given in Table 2. As seen in Table 2, decomposition temperatures $\left(T_{\mathrm{i}}, T_{\max }\right.$, and $\left.T_{\mathrm{f}}\right)$ of the molecules are different from each other. All molecules exhibit a one-step weight change in the range of $243-370{ }^{\circ} \mathrm{C}$. The 3a-g compounds are thermally stable up to $70,70,90,85,100,70$ and $108{ }^{\circ} \mathrm{C}$, respectively. In the decomposition process of the 3a-g molecules, the mass losses corresponded to absorption $\mathrm{H}_{2} \mathrm{O}$ or DMSO leaving in the first stages of the decomposition.

Characteristic IR spectral data of the Schiff bases are given at Table 3. It was concluded from TGA analysis that crystal water was found in all synthesized Schiff bases. The peaks that were observed in the range $3136-3181 \mathrm{~cm}^{-1}$ may be attributed to the $v(\mathrm{O}-\mathrm{H}), v\left(\mathrm{H}_{2} \mathrm{O}\right)$ or $v\left(\operatorname{aryl} l-\mathrm{N}-\mathrm{H}^{+}\right)$ (Fig. 1). The aromatic -C-H stretching bands of all Schiff bases were predicted to be in the range 2933-2952 $\mathrm{cm}^{-1}$, and the cyclo-C-H stretching bands of all Schiff bases were predicted to be in the range $2858-2871 \mathrm{~cm}^{-1}$. The observation of bands in the range $1653-1659 \mathrm{~cm}^{-1}$ may be attributed to the $v(-\mathrm{CH}=\mathrm{N}-)$. The observation of bands at 1133, 1179 and $1032 \mathrm{~cm}^{-1} ; 768$ and 700 $\mathrm{cm}^{-1} ; 592 \mathrm{~cm}^{-1}$; and 784 and $705 \mathrm{~cm}^{-1}$ may be attributed to the $v(\mathrm{C}-\mathrm{Z})$, where $\mathrm{Z}=\mathrm{F}, \mathrm{Cl}, \mathrm{Br}$ and $\mathrm{Me}$, respectively. 
Table 2

Thermal data of Schiff base derivatives of tacrine

\begin{tabular}{ccccc}
\hline \hline Compound & $T_{\text {crystalwater }}$ & $T_{\mathrm{i}}$ & $T_{\max }$ & $T_{\mathrm{f}}$ \\
\hline 3a & $70-125$ & 308 & 325 & 358 \\
3b & $70-113$ & 250 & 305 & 318 \\
3c & $90-160$ & 275 & 310 & 338 \\
3d & $85-138$ & 318 & 345 & 370 \\
3e & $100-258^{*}$ & 305 & 325 & 365 \\
3f & $70-130$ & 313 & 338 & 363 \\
3g & $108-110$ & 243 & 273 & 305 \\
\hline \hline
\end{tabular}

$T_{\mathrm{i}}$ : Initial degradation temperature $\left({ }^{\circ} \mathrm{C}\right)$.

$T_{\max }$ : Maximum degradation temperature $\left({ }^{\circ} \mathrm{C}\right)$.

$T_{\mathrm{f}}$ : Final degradation temperature $\left({ }^{\circ} \mathrm{C}\right)$.

*This derivative has both crystal water and DMSO.

Table 3

Important IR vibration frequencies $\left(\mathrm{cm}^{-1}\right)$ of Schiff bases

\begin{tabular}{|c|c|c|c|c|c|}
\hline Compound & $v_{\mathrm{NH} 2}$ & $v_{-\mathrm{CH}=\mathrm{N}}$ & $v_{\mathrm{O}-\mathrm{H}, \mathrm{H} 2 \mathrm{O}, \text { aryl }-\mathrm{N}-\mathrm{H}+}$ & $\begin{array}{c}v_{\mathrm{C}-\mathrm{H}}(\text { aromatic }) \\
v_{\mathrm{C}-\mathrm{H}}(\text { cyclo })\end{array}$ & $v_{\mathrm{C}-\mathrm{Z}}$ \\
\hline Tacrine & $\begin{array}{l}3333 \\
3175\end{array}$ & - & - & $\begin{array}{l}2933 \\
2871\end{array}$ & - \\
\hline 3a & - & 1654 & 3181 & $\begin{array}{l}2952 \\
2865\end{array}$ & $\begin{array}{c}1032 \\
705\end{array}$ \\
\hline $3 \mathbf{b}$ & - & 1653 & 3149 & $\begin{array}{l}2945 \\
2858\end{array}$ & 784 \\
\hline $3 c$ & - & 1657 & 3149 & $\begin{array}{l}2945 \\
2861\end{array}$ & $\begin{array}{c}700 \\
1179\end{array}$ \\
\hline 3d & - & 1653 & 3174 & $\begin{array}{l}2945 \\
2874\end{array}$ & 592 \\
\hline $3 e$ & - & 1630 & 3131 & $\begin{array}{l}2943 \\
2870\end{array}$ & 768 \\
\hline $3 f$ & - & 1659 & 3156 & $\begin{array}{l}2945 \\
2881\end{array}$ & 1133 \\
\hline $3 g$ & - & 1657 & 3172 & $\begin{array}{l}2934 \\
2865\end{array}$ & - \\
\hline
\end{tabular}

The ${ }^{1} \mathrm{H}-\mathrm{NMR}$ data of the Schiff bases are presented in Table 4. In general, the duplets observed at 8.15-8.6 ppm were assigned to Schiff base $-\mathrm{C} \underline{\mathrm{H}}=\mathrm{N}-$ proton. Multiplets observed at 2.4-3.8 ppm were assigned to $-\underline{\mathrm{CH}}_{\mathrm{a}}$ and $-\underline{\mathrm{C}}_{\mathrm{c}}$ protons of tacrine's cyclo ring. Multiplets observed at 1.7-2.3 ppm were assigned to tacrine's $-\mathrm{CH}_{\mathrm{b}}$ protons. Multiplets at 7.4-8.8 ppm and 6.8-7.6 ppm were assigned to tacrine's and aldehydes' $-\underline{\mathrm{H}}_{\text {aryl }}$ protons, respectively. Singlets observed at 10.2-14.0 ppm were assigned to $-\mathrm{OH}$ protons. The protons of $-\underline{\mathrm{CH}}_{3}$ of aldehyde moieties in the Schiff bases were also observed as expected.

The ${ }^{13} \mathrm{C}-\mathrm{NMR}$ spectral data of the Schiff bases (Table 5) are also in accordance with the proposed structures. In general, the peaks observed at 155.16-162.548 ppm and 135.57-157.39 ppm were assigned to the aromatic ring carbons attached to the $-\mathrm{CH}=\mathrm{N}-$ and $-\mathrm{OH}$ groups, respectively. Peaks corresponding to the $-\mathrm{C}-\mathrm{X}$ and $-\mathrm{C}-\mathrm{Y}$ residues of the Schiff bases were also observed as expected. 
Table 4

${ }^{1}$ H-NMR chemical shifts (ppm) of Schiff base derivatives of tacrine

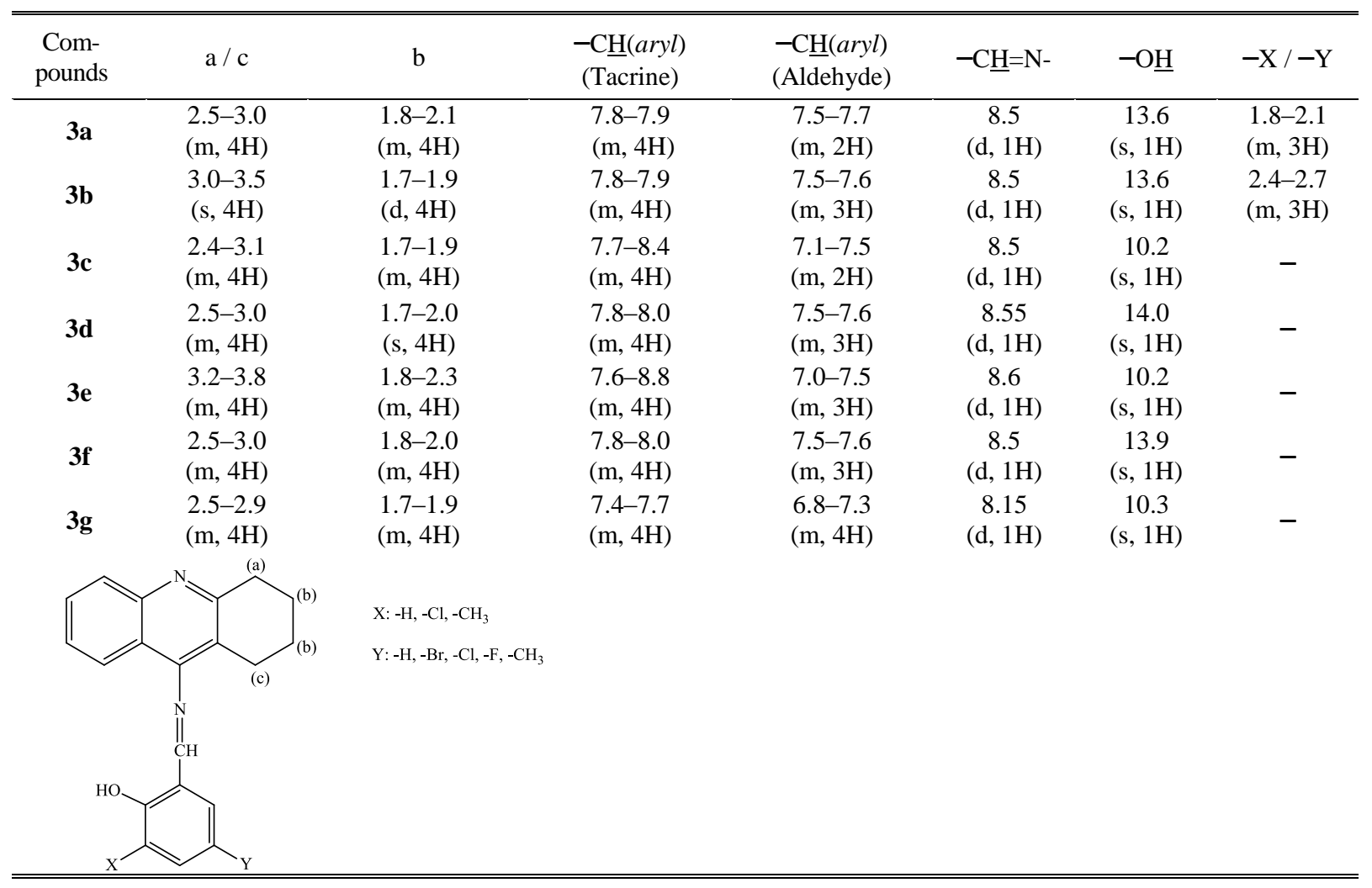

Table 5

${ }^{13} \mathrm{C}$-NMR chemical (ppm) of Schiff base derivatives of tacrine

\begin{tabular}{|c|c|c|c|c|c|c|c|c|}
\hline $\begin{array}{l}\text { Com- } \\
\text { pounds }\end{array}$ & $\mathrm{C}_{1-5}$ & $\mathrm{C}_{6-9}$ & $\begin{array}{l}\mathrm{C}_{10} \\
\mathrm{C}_{10^{\mathrm{a}}}\end{array}$ & $\mathrm{C}_{11}$ & $\mathrm{C}_{12-15}$ & $\begin{array}{c}-\mathrm{N}=\mathrm{CH} \\
\mathrm{C}_{-} \mathrm{OH}\end{array}$ & $\begin{array}{l}-\mathrm{C}-\mathrm{X} \\
-\mathrm{CH}_{3}\end{array}$ & $\begin{array}{l}-\mathrm{C}-\mathrm{Y} \\
-\mathrm{CH}_{3}\end{array}$ \\
\hline 3a & $39.44-40.55$ & $28.41-109.51$ & $\begin{array}{l}21.55 \\
23.07\end{array}$ & 39.16 & $115.29-133.12$ & $\begin{array}{l}155.56 \\
152.02\end{array}$ & $\begin{array}{l}119.79 \\
21.04\end{array}$ & $\begin{array}{c}137.83 \\
-\end{array}$ \\
\hline 3b & $39.43-40.54$ & 28.19-133.30 & $\begin{array}{l}21.50 \\
23.02\end{array}$ & 39.15 & $115.20-137.49$ & $\begin{array}{l}155.82 \\
151.80\end{array}$ & $\begin{array}{c}119.46 \\
-\end{array}$ & $\begin{array}{l}109.52 \\
20.96\end{array}$ \\
\hline $3 c$ & $39.15-40.55$ & $23.13-120.30$ & $\begin{array}{l}21.17 \\
21.64\end{array}$ & 28.74 & $109.52-132.85$ & $\begin{array}{l}155.16 \\
152.37\end{array}$ & $\begin{array}{c}125.61 \\
-\end{array}$ & $\begin{array}{c}138.36 \\
-\end{array}$ \\
\hline 3d & $39,14-40.54$ & $23.04-115.19$ & $\begin{array}{l}20.96 \\
21.51\end{array}$ & 28.19 & $123.91-137.55$ & $\begin{array}{l}155.71 \\
151.75\end{array}$ & $\begin{array}{c}119.46 \\
-\end{array}$ & $\begin{array}{c}109.43 \\
-\end{array}$ \\
\hline $3 e$ & $31.59-40.81$ & $23.12-110.56$ & $\begin{array}{l}19.19 \\
22.11\end{array}$ & 23.99 & $112.08-133.41$ & $\begin{array}{l}155.58 \\
135.57\end{array}$ & $\begin{array}{c}119.6 \\
-\end{array}$ & $\begin{array}{c}123.45 \\
-\end{array}$ \\
\hline $3 f$ & $39.15-40.55$ & $23.03-109.51$ & $\begin{array}{l}20.96 \\
21.50\end{array}$ & 28.19 & $115.20-133.28$ & $\begin{array}{l}155.81 \\
151.79\end{array}$ & $\begin{array}{c}119.45 \\
-\end{array}$ & $\begin{array}{c}137.49 \\
-\end{array}$ \\
\hline $3 g$ & $39.15-40.54$ & $24.05-109.34$ & $\begin{array}{l}22.91 \\
22.97\end{array}$ & 33.61 & $117.37-149.01$ & $\begin{array}{l}162.54 \\
157.39\end{array}$ & $\begin{array}{c}128.63 \\
-\end{array}$ & $\begin{array}{c}129.24 \\
-\end{array}$ \\
\hline & & $\begin{array}{l}\mathrm{X}:-\mathrm{H},-\mathrm{Cl},-\mathrm{CH} / \\
\mathrm{Y}:-\mathrm{H},-\mathrm{Br},-\mathrm{Cl},-\mathrm{F},\end{array}$ & & & & & & \\
\hline
\end{tabular}




\subsection{AChE inhibitory activity and kinetic studies}

AChE activity of the synthesized compounds was investigated, and $\mathrm{IC}_{50}, K_{\mathrm{i}}, K_{\mathrm{M}}$, and $V_{\max }$ values were calculated by the spectrophotometric Ellman method [35] (Fig. 3). IC $_{50}$ (the molarity of inhibitor causing a $50 \%$ decrease of enzyme activity, Fig. S1), $K_{\mathrm{i}}$ (inhibitor-enzyme dissociation constant), $K_{\mathrm{M}}$ (Michaelis-Menten constant), and $V_{\max }$ (maximum reaction velocity) values and inhibition types are given in Table $6 . K_{\mathrm{i}}$ values were calculated from Lineweaver-Burk graphs (Fig. S2). As seen in Table 6, all the compounds behave as inhibitors against AChE. It was seen that all compounds had the property of a water-soluble reversible AChE inhibitor. The inhibition potency of the compounds indicates an increasing inhibitory effect on AChE as follows: $\mathbf{3 a}>\mathbf{3 b}>\mathbf{3 g}>\mathbf{3} \mathbf{c}>$ 3f $>$ 3d $>$ 3e. When the inhibitory potency of compounds was compared with respective to $K_{\mathrm{i}}$ values, same ranking was observed (except 3e) (Table 6). The best AChE inhibition potency was observed for 3a, with $\mathrm{IC}_{50}$ value of $22.1 \pm 1.11 \mathrm{nM}$, showing superior activity to that of tacrine reference drug. It was concluded that the synthesized compounds showed more activity than tacrine, because $\mathrm{IC}_{50}$ values of those compounds were lower than tacrine's $\mathrm{IC}_{50}$ value $(34.1 \mathrm{nM})$ (except $\mathbf{3 e}$, because it was synthesized in DMSO, resulting in a structure crystallization, its increased molecular mass caused reduced water solubility, so its inhibition potency was reduced compared to other inhibitors in the series).

Luo and co-workers have reported that the hydroxyl group on the benzene ring of the molecule they synthesized, could form hydrogen bonds with residues in the binding site of cholinesterase $[36,37]$. In our study, salicylaldehyde and its derivatives have a hydroxyl group on their benzene ring. So, it could be that this hydroxyl group is important for inhibitor activity.

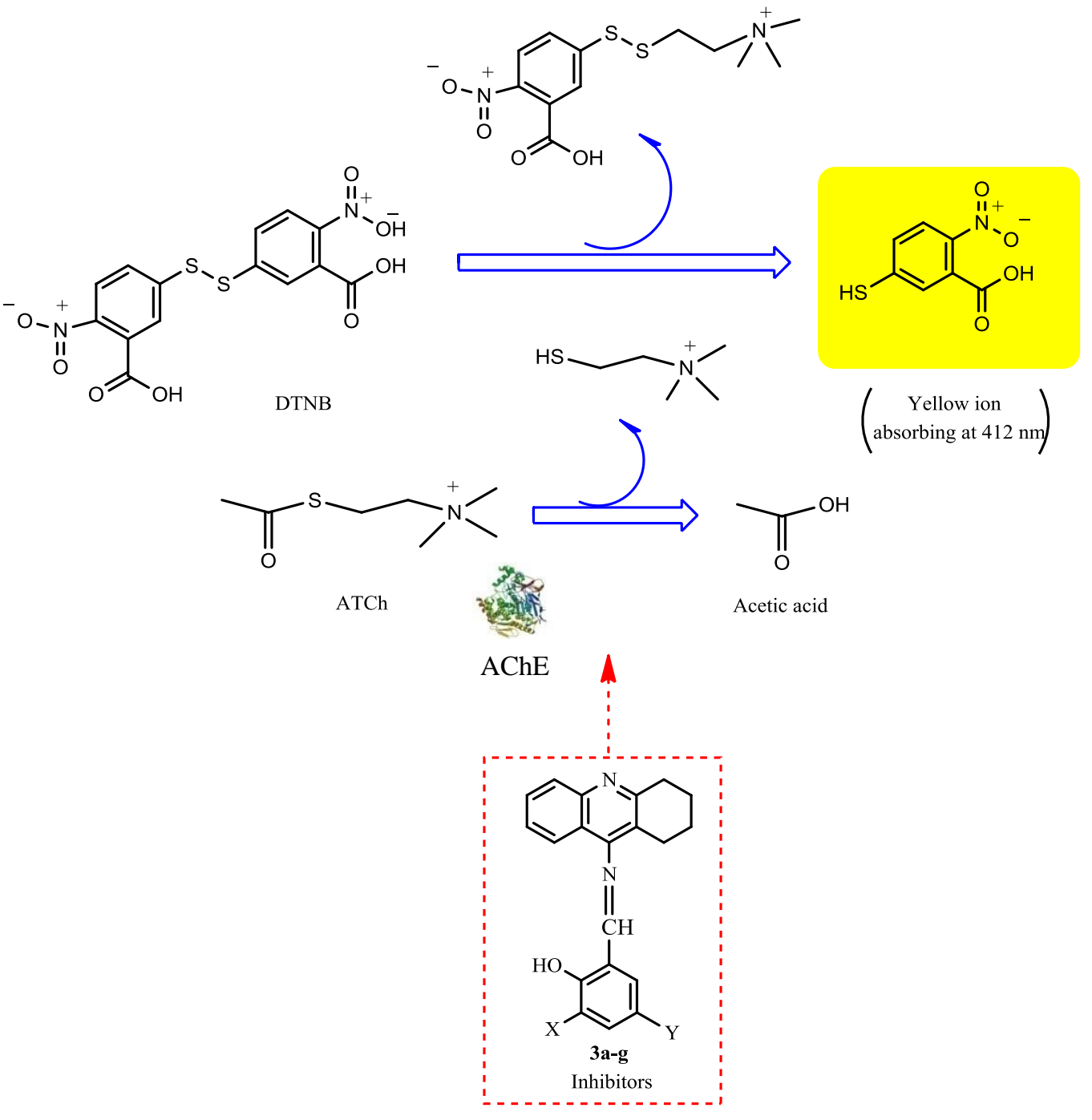

Fig. 3. AChE activity assay by Ellman method 
Table 6

The result of inhibition studies of tacrine derivatives on AChE

\begin{tabular}{cccccc}
\hline \hline Compounds & $\begin{array}{c}\mathrm{IC}_{50} \\
(\mathrm{nM})\end{array}$ & $\begin{array}{c}K_{\mathrm{i}} \\
(\mathrm{mM})\end{array}$ & $\begin{array}{c}K_{\mathrm{M}} \\
(\mathrm{mM})\end{array}$ & $\begin{array}{c}V_{\max } \\
(\mathrm{mM} / \mathrm{min})\end{array}$ & Inhibition type \\
\hline 3a & $22.1 \pm 1.11$ & $2.14 \pm 0.89$ & $0.145 \pm 0.023$ & $0.066 \pm 0.003$ & Mixed \\
$\mathbf{3 b}$ & $23.9 \pm 1.10$ & $3.77 \pm 1.28$ & $0.179 \pm 0.015$ & $0.106 \pm 0.003$ & Mixed \\
$\mathbf{3 c}$ & $27.5 \pm 1.10$ & $13.6 \pm 2.18$ & $0.170 \pm 0.035$ & $0.103 \pm 0.007$ & Noncompetitive \\
$\mathbf{3 d}$ & $32.1 \pm 1.11$ & $21.9 \pm 2.38$ & $0.159 \pm 0.015$ & $0.066 \pm 0.002$ & Uncompetitive \\
$\mathbf{3 e}$ & $730.0 \pm 1.52$ & $14.86 \pm 4.7$ & $0.157 \pm 0.057$ & $0.059 \pm 0.008$ & Uncompetitive \\
$\mathbf{3 f}$ & $30.5 \pm 1.09$ & $17.3 \pm 1.34$ & $0.202 \pm 0.022$ & $0.111 \pm 0.005$ & Noncompetitive \\
$\mathbf{3 g}$ & $25.0 \pm 1.32$ & $10.2 \pm 0.79$ & $0.218 \pm 0.020$ & $0.110 \pm 0.004$ & Uncompetitive \\
\hline \hline
\end{tabular}

AChE inhibition activity is highly dependent on substituents $\mathrm{X}$ and $\mathrm{Y}$ in compounds $\mathbf{3 a}-\mathbf{g}$. The most active compound, 3a, has 3-methyl and 5fluoro groups as substituents. It was seen that $\mathbf{3 a}$ was 1.5 -fold more active than tacrine.

When inhibitors containing only halogen substituents (X: $-\mathrm{H}, \mathrm{Y}$ : -halogen substituent, $\mathbf{3 f}<$ $\mathbf{3 d}<3 \mathbf{3 e}$, ranked according to $\mathrm{IC}_{50}$ values) were compared, no connection could be obtained between the electronegativity of substituents and inhibitor activity. The best inhibitor activity was obtained from inhibitor containing fluorine substituent (3f). In the literature, an analogous result was seen in Mohsen's work [38]. When the most active inhibitors (3a and $\mathbf{3 b}$ ) were compared, the inhibitor containing -F substituent (3a) was more active than the inhibitor lacking $-\mathrm{F}(\mathbf{3 b})$. When $\mathbf{3 c}$ and $\mathbf{3 e}$ inhibitors, containing $-\mathrm{Cl}$ substituents, were compared, results showed that inhibitor containing $-\mathrm{F}$ substituent (3c) was more active than inhibitor lacking $-\mathrm{F}(\mathbf{3 e})$. It was evident from all these results that $-\mathrm{F}$ substituent increased the inhibitory activity.

The most active inhibitors' ( $\mathbf{3 a}$ and $\mathbf{3 b}$ ) inhibition types were determined as mixed-type. Accordingly, inhibitors can bind both free enzyme and enzyme-substrate complex, but their binding affinities are different [39].

When the series was compared within itself, the most active inhibitors were determined as $\mathbf{3 a}$. It includes a $-\mathrm{CH}_{3}$ substituent. In the literature, the best inhibitor activity was seen for inhibitors containing an electron-donating $-\mathrm{CH}_{3}$ substituent [40, 41].

\section{CONCLUSIONS}

In summary, novel tacrine derivatives have been synthesized, and their inhibitory activity against $\mathrm{AChE}$ enzyme was investigated. Character- izations of the synthesized compounds were made by using elemental analysis and spectroscopic methods. All the synthesized compounds behaved as inhibitors against $\mathrm{AChE}$ and had the property of a water-soluble reversible AChE inhibitor. These inhibitors showed more activity than tacrine (except 3e). The greatest inhibition potency was obtained from 3a. In the literature, there are a few studies of Schiff base derivatives of AChE inhibitors [27, 42, 43]. So, this work can contribute for synthesizing new Schiff base derivatives of AChE inhibitors and points a way to potential new therapies of $\mathrm{AD}$.

Acknowledgements. This research did not receive any specific grant from funding agencies in the public, commercial, or not-for-profit sectors.

\section{REFERENCES}

[1] H. Gocer, F. Topal, M. Topal, M. Küçük, D. Teke, İ. Gülçin, S. H. Alwasel, C. T. Supuran, Acetylcholinesterase and carbonic anhydrase isoenzymes I and II inhibition profiles of taxifolin, J. Enzyme Inhib. Med. Chem., 31 (3), 441-447 (2016).

DOI: https://doi.org/10.3109/14756366.2015.1036051

[2] S. Akhondzadeh, M. Noroozian, M. Mohammadi, S. Ohadinia, A. H. Jamshidi, M. Khani, Salvia officinalis extract in the treatment of patients with mild to moderate Alzheimer's disease: a double blind, randomized and placebo-controlled trial, J. Clin. Pharm. Ther., 28 (1), 53-59 (2003).

DOI: https://doi.org/10.1046/j.1365-2710.2003.00463.x

[3] A. Dişli, M. Gümüş, K. Ünal, N. Sarı, F. Arslan, New multifunctional agents and their inhibitory effects on the acetyl cholinesterase enzyme, Maced. J. Chem. Chem. Eng., 37 (1), 21-34 (2018). DOI: http://dx.doi.org/10.20450/mjcce.2018.1334

[4] A. Nordberg, A. L. Svensson, Cholinesterase inhibitors in the treatment of Alzheimer's disease, Drug Safety, 19 (6), 465-480 (1998). DOI: https://doi.org/10.2165/00002018-199819060-00004

[5] S. Rizzo, C. Riviere, L. Piazzi, A. Bisi, S. Gobbi, M. Bartolini, V. Andrisano, F. Morroni, A. Tarozzi, J. P. Monti, A. Rampa, Benzofuran-based hybrid compounds 
for the inhibition of cholinesterase activity, $\beta$ amyloid aggregation, and $\mathrm{A} \beta$ neurotoxicity, J. Med. Chem., 51 (10), 2883-2886 (2008). DOI: 10.1021/jm8002747

[6] E. Aynac1, A. Yaşar, F. Arslan, An amperometric biosensor for acetylcholine determination prepared from acetylcholinesterase-choline oxidase immobilized in polypyrrole-polyvinylsulpfonate film, Sens Actuators B: Chem. 202, 1028-1036 (2014).

DOI: https://doi.org/10.1016/j.snb.2014.06.049

[7] A. T. Tunç, E. Aynacı Koyuncu, F. Arslan, Development of an acetylcholinesterase-choline oxidase based biosensor for acetylcholine determination, Artif. Cells, Nanomed. and Biotechnol., 44 (7), 1-6 (2015). DOI: https://doi.org/10.3109/21691401.2015.1080167

[8] J. Baek, H. L. Lee, K. S. Kang, K. H. Kim, Chemical constituents from the fruit of Citrus unshiu and their inhibitory effects on acetylcholinesterase, Maced. J. Chem. Chem. Eng., 36 (1), 15-2 (2017). DOI: http://dx.doi.org/10.20450/mjcce.2017.1139

[9] D. Cör1, T. Botić, Ž. Knez, A. Gregori, F. Pohleven, The effects of different solvents on bioactive metabolites and "in vitro" antioxidant and anti-acetylcholinesterase activity of Ganoderma lucidum fruiting body and primordia extracts, Maced. J. Chem. Chem. Eng., 36 (1), 129-141 (2017).

DOI: http://dx.doi.org/10.20450/mjcce.2017.1054

[10] P. T. Francis, A. M. Palmer, M. Snape, G. K. Wilcock, The cholinergic hypothesis of Alzheimer's disease: a review of progress, J. Neurol. Neurosur. Ps. 66 (2), 137-147 (1999).

[11] B. Halfon, E. Çiftçi, G. Topçu. Flavonoid constituents of Sideritis caesarea, Turk. J. Chem. 37, 464-472 (2013). DOI: $10.3906 / \mathrm{kim}-1206-45$

[12] J. C. Jaén, V. E. Gregor, C. Lee, R. Davis, M. Emmerling, Acetylcholinesterase inhibition by fused dihydroquinazoline compounds, Bioorg. Med. Chem. Lett., 6 (6), 737-742 (1996). DOI: https://doi.org/10.1016/0960-894X(96)00102-3

[13] M. Pohanka, Cholinesterases, a target of pharmacology and toxicology, Biomedical papers., 155 (3), 219-223 (2011). DOI: $10.5507 / \mathrm{bp} .2011 .036$

[14] I. Silman, J. L. Sussman, Acetylcholinesterase: how is structure related to function?, Chem Biol Interact. 175, 3-10 (2008).

DOI: https://doi.org/10.1016/j.cbi.2008.05.035

[15] M. Pohanka, J. Zdarova Karasova, K. Kuca, J. Pikula, Multichannel spectrophotometry for analysis of organophosphate paraoxon in beverages, Turk. J. Chem. 34, 91-98 (2010). DOI: 10.3906/kim-0903-7

[16] Z. Kovarik, Z. Radic, H. A. Berman, V. Simeon-Rudolf, E. Reiner, P. Taylor, Acetylcholinesterase active centre and gorge conformations analysed by combinatorial mutations and enantiomeric phosphonates, Biochem. J. 373, 33-40 (2003). DOI: 10.1042/bj20021862

[17] C. Bartolucci, L. A. Haller, U. Jardis, G. Fels, D. Lamba, Probing Torpedo Californica acetylcholinesterase catalytic gorge with two novel bisfunctional galanthamine derivatives, $J$ Med Chem. 53, 745-51(2010). DOI: 10.1021/jm901296p

[18] H. J. Kreienkamp, C. Weise, R. Raba, A. Aaviksaar, F. Hucho, Anionic subsites of the catalytic center of acetylcholinesterase from Torpedo and from cobra venom, Proc. Natl. Acad. Sci. USA., 88, 6117-6121 (1991). DOI: https://doi.org/10.1073/pnas.88.14.6117

[19] G. Orhan, İ. Orhan, N. Subutay-Öztekin, F. Ak, B. Şener, Contemporary anticholinesterase pharmaceuticals of natural origin and their synthetic analogues for the treatment of Alzheimer's disease, Recent Patents on CNS Drug Discovery. 4, 43-51 (2009). DOI: https://doi.org/10.2174/157488909787002582

[20] H. Shaw, G. Bentley, Anticholinesterase properties of tetrahydroaminoacridine, Aust. J. Exp. Biol. 31, 573-578 (1953).

[21] W. K. Summers, L. V. Majovski, G. M. Marsh, K. Tachiki, A. Kling, Oral tetrahydroaminoacridine in longterm treatment of senile dementia, Alzheimer type, New Engl. J. Med., 315, 1241-1245 (1986). DOI: 10.1056/NEJM198611133152001

[22] M. Harel, I. Schalk, L. Ehret-Sabatier, F. Bouet, M. Goeldner, C. Hirth, P. H. Axelsen, I. Silman, J. L. Sussman, Quaternary ligand binding to aromatic residues in the active-site gorge of acetylcholinesterase, Proc. Natl. Acad. Sci., 90 (19), 9031-9035 (1993).

[23] H. Khalid, A. U. Rehman, M. A. Abbasi, R. Hussain, K. M. Khan, M. Ashraf, S. A. Ejaz, M. Q. Fatmi, Synthesis, biological evaluation, and molecular docking of $\mathrm{N}$ (Aryl/alkylsulfonyl)-1-(phenylsulfonyl) piperidine-4carbohydrazide derivatives, Turk. J. Chem, 38, 189-201 (2014). DOI: 10.3906/kim-1303-89

[24] İ. Şakıyan, E. Aynacı Koyuncu, F. Arslan, H. Öğütçü, N. Sar1, Some novel antimicrobial therapeutic agents for acetylcholinesterase inhibitors; synthesis of hydroxyquinoline ester involving amino acid, G. U. J. Sci. 28 (1), 11-19(2015).

[25] D. Schuster, M. Spetea, M. Music, S. Rief, M. Fink, J. Kirchmair, J. Schütz, G. Wolber, T. Langer, H. Stuppner, et al., Morphinans and isoquinolines: acetylcholinesterase inhibition, pharmacophore modeling, and interaction with opioid receptors, Bioorg. Med. Chem. 18, 5071-5080 (2010). DOI: https://doi.org/10.1016/j.bmc.2010.05.071

[26] S. Yılmaz, Y. Akbaba, B. Özgeriş, L. P. Köse, S. Göksu, İ. Gülçin, S. H. Alwasel, C. T. Supuran, Synthesis and inhibitory properties of some carbamates on carbonic anhydrase and acetylcholine esterase, J. Enzyme Inhib. Med. Chem., Early Online 1-8 (2016). DOI: https://doi.org/10.3109/14756366.2016.1149477

[27] B. Turan, K. Şendil, E. Şengül, M. S. Gültekin, P. Taslimi, İ. Gulçin, C. T. Supuran, The synthesis of some $\beta$-lactams and investigation of their metal-chelating activity, carbonic anhydrase and acetylcholinesterase inhibition profiles, J. Enzyme Inhib. Med. Chem. Early Online, 1-10 (2016). DOI: https://doi.org/10.3109/14756366.2016.1170014

[28] S. Singla, P. Piplani, Coumarin derivatives as potential inhibitors of acetylcholinesterase: Synthesis, molecular docking and biological studies, Bioorg. Med. Chem. 24, 4587-4599 (2016).

DOI: https://doi.org/10.1016/j.bmc.2016.07.061

[29] M. I. Rodríguez-Franco, M. I. Fernández-Bachiller, C. Pérez, B. Hernández-Ledesma, B. Bartolomé, Novel tacrine-melatonin hybrids as dual-acting drugs for Alzheimer disease, with improved acetylcholinesterase 
inhibitory and antioxidant properties, J. Med. Chem. 49, 459-462 (2006). DOI: 10.1021/jm050746d

[30] M. I Fernández-Bachiller, C. Pérez, N. E. Campillo, J. A. Páez, G. C. González-Muñoz, P. Usan, E. GarcíaPalomero, M. G. López, M. Villaroya, A. G. García, et al., Tacrine-melatonin hybrids as multifunctional agents for Alzheimer's disease, with cholinergic, antioxidant, and neuroprotective properties, Chem. Med. Chem., 4 (5), 828-841, (2009).

DOI: https://doi.org/10.1002/cmdc.200800414

[31] L. Fang, B. Kraus, J. Lehmann, J. Heilmann, Y. Zhang, M. Decker, Design and synthesis of tacrine-ferulic acid hybrids as multi-potent anti-Alzheimer drug candidates, Bioorg. Med. Chem. Lett. 18, 2905-2909 (2008). DOI: https://doi.org/10.1016/j.bmcl.2008.03.073

[32] M. Benchekroun, M. Bartolini, J. Egea, A. Romero, E. Soriano, M. Pudlo, V. Luzet, V. Andrisano, M. N. Jimeno, M. G. Lopéz, et al., Novel tacrine-grafted ugi adducts as multipotent anti-Alzheimer drugs: A synthetic renewal in tacrine-ferulic acid hybrids, ChemMedChem., 10 (3), 523-539 (2015). DOI: https://doi.org/10.1002/cmdc.201402409

[33] M. Rosini, E. Simoni, M. Bartolini, A. Tarozzi, R. Matera, A. Milelli, Exploiting the lipoic acid structure in the search for novel multitarget ligands against Alzheimer's disease, Eur. J. Med. Chem. 46, 5435-5442 (2011). DOI: https://doi.org/10.1016/j.ejmech.2011.09.001

[34] Z. Liu, L. Fang, H. Zhang, S. Gou, L. Chen, Design, synthesis and biological evaluation of multifunctional tacrine-curcumin hybrids as new cholinesterase inhibitors with metal ions-chelating and neuroprotective property, Bioorg. Med. Chem. 25, 2387-2398 (2017). DOI: https://doi.org/10.1016/j.bmc.2017.02.049

[35] G. L. Ellman, K. D. Courtney, V. Andres, R. M. Featherstone, A new and rapid colorimetric determination of acetylcholinesterase activity, Biochem. Pharmacol. 7 (2), 88-95 (1961). DOI: https://doi.org/10.1016/0006-2952(61)90145-9

[36] W. Luo, Y. P. Li, Y. He, S. L. Huang, D. Li, L.Q. Gu, Z. S. Huang, Synthesis and evaluation of heterobivalent tacrine derivatives as potential multi-functional antiAlzheimer agents, Eur. J. Med. Chem. 46 (6), 26092616 (2011).

DOI: https://doi.org/10.1016/j.ejmech.2011.03.058

[37] Q. Xie, H. Wang, Z. Xia, M. Lu, W. Zhang, X. Wang, W. Zhou, Bis-(-)-nor-meptazinols as novel nanomolar cholinesterase inhibitors with high inhibitory potency on amyloid- $\beta$ aggregation, J. Med. Chem. 51 (7), $2027-$ 2036 (2008). DOI: 10.1021/jm070154q

[38] U. A. Mohsen, Studies on imidazopyridine derivatives as acetylcholinesterase inhibitors, Journal of Marmara University Institute of Health Sciences. 2 (3), 119-123 (2012).

[39] E. Keha, İ. Küfrevioğlu, Biyokimya, $6^{\text {th }}$ Edition, Aktif Yayınevi, İstanbul, 2009, pp. 93-95, 116-123.

[40] L. Huang, Z. Luo, F. He, J. Lu, X. Li, Synthesis and biological evaluation of a new series of berberine derivatives as dual inhibitors of acetylcholinesterase and butyrylcholinesterase, Bioorgan. Med. Chem. 18 (12), 4475-4484 (2010). DOI: https://doi.org/10.1016/j.bmc.2010.04.063

[41] A. Rehman, A. Fatima, N. Abbas, M. A. Abbasi, K. M. Khan, M. Ashraf, I. Ahmad, S. A. Ejaz, Synthesis, characterization and biological screening of 5-substituted1, 3, 4-oxadiazole-2yl-N-(2-methoxy-5-chlorophenyl)-2sulfanyl acetamide, Pak. J. Pharm. Sci. 26(2) 345-352 (2013).

[42] R. Raza, A. Saeed, M. Arif, S. Mahmood, M. Muddassar, A. Raza, J. Iqbal, Synthesis and biological evaluation of 3-thiazolocoumarinyl schiff-base derivatives as cholinesterase inhibitors, Chem. Biol. Drug. Des. 80 (4), 605-615 (2012).

DOI: https://doi.org/10.1111/j.1747-0285.2012.01435.x

[43] N. S. Gwaram, H. M. Ali, M. A. Abdulla, M. J. Buckle, S. D. Sukumaran, L. Y. Chung, P. Hassandarvish, Synthesis, characterization, X-ray crystallography, acetyl cholinesterase inhibition and antioxidant activities of some novel ketone derivatives of gallic hydrazide-derived Schiff bases, Molecules, 17 (3), 2408-2427 (2012). DOI: https://doi.org/10.3390/molecules 17032408 